\title{
Efficiency of cotton bollworm (Helicoverpa armigera Hübner) control of different $B t$ cotton varieties in North China
}

\author{
LÜ Limin ${ }^{1 \dagger}$, LUO Junyu ${ }^{1 \dagger}$, ZHANG Shuai ${ }^{1}$, YU Qianlin², MA Ligang ${ }^{3}$, LIU Xiaofeng ${ }^{4}$, WANG Chunyi ${ }^{1}$, MA Xiaoyan ${ }^{1}$, \\ MA Yan ${ }^{1 *}$ and CUI Jinjie ${ }^{1 *}$
}

\begin{abstract}
Background: The cotton bollworm (Helicoverpa armigera) is one of cotton's most destructive insect pests in terms of yield and quality. Since 1997, China has grown commercially available transgenic Bacillus thuringiensis (Bt) cotton. We aimed to investigate the variation in resistance of transgenic Bt cotton varieties to cotton bollworm in North China.

Methods: Populations of cotton bollworm were monitored from 2008 to 2015 in environments where Bt cotton was planted adjacent to other non-Bt crops. The study included 197 Bt cotton varieties planted in 42 counties/locations in three provinces (Hebei, Shandong and Henan) of North China, which were evaluated through field investigations, bioassays, and enzyme-linked immunosorbent assays (ELISA).

Results: The average number of cotton bollworms never exceeded the action threshold (10 larvae per 100 cotton plants), however, their number reached 19.55 per 100 cotton plants in 2011. The ratios of damaged plants to total Bt cotton stem-tips, buds, and bolls was low except in 2010, when the ratios reached 1.82\%, 2.09\%, and 10.63\%, respectively. The results of bioassay showed that the corrected mortality were higher at the second generation cotton bollworm stage than the third and fourth germination stages. Totally, Bt protein content declined sharply at the seedling stage from 2008 to 2015.

Conclusions: This study indicated that almost all Bt cotton varieties were capable to effectively control the populations of cotton bollworm in North China.
\end{abstract}

Keywords: Upland cotton, North China, Bt cotton varieties, Cotton bollworm, Efficiency evaluation

\section{Background}

The cotton bollworm, Helicoverpa armigera Hübner, is one of cotton's most destructive insect pests. In the 1990s, both cotton yield and quality were severely affected by cotton bollworm outbreaks in major cotton production provinces of China. Since 1997, China has grown commercially available transgenic Bacillus thuringiensis $(B t)$ cotton. Since its introduction, $B t$ cotton has been produced on a large scale in three provinces of Hebei, Shandong, and Henan in China (Liu et al. 2010; Wu and Guo 2005; Wu et al. 2008).

\footnotetext{
*Correspondence: aymayan@126.com; aycuijinjie@163.com

${ }^{\dagger}$ Lü Limin and Luo Junyu contributed equally to this work.

'Institute of Cotton Research, Chinese Academy of Agricultural Sciences (CAAS), State Key Laboratory of Cotton Biology, Anyang 455000, Henan, China

Full list of author information is available at the end of the article
}

Transgenic $B t$ cotton has been grown for 19 years in China. Over time, and as the plantation areas for $B t$ cotton have expanded, cotton bollworms have become increasingly resistant to Bt insecticidal proteins, prompting researchers to conduct investigations (Liu et al. 2010; Zhang et al. 2011). Bt-resistant cotton bollworm strains have been reported to have 28,93.3-fold higher resistance than susceptible strains when fed $B t$ toxins in the laboratory (Liang et al. 2008).

The mechanism of bollworm resistance has been investigated in the laboratory, with particular focus on the Bt insecticidal protein (Gunning et al. 2005; Zhang et al. 2009). Field-evolved resistance of cotton bollworm to $B t$ crops has been documented in several countries (Dhurua and Gujar 2011; Van Rensburg 2007; Zhang et al. 2011). In field-selected populations, recessive cadherin alleles

(c) The Author(s). 2018 Open Access This article is distributed under the terms of the Creative Commons Attribution 4.0 International License (http://creativecommons.org/licenses/by/4.0/), which permits unrestricted use, distribution, and 
accounted for $75-84 \%$ of the resistance alleles detected; most resistance alleles occur as heterozygotes, and $59-94 \%$ of the resistant individuals carried at least one recessive resistance allele (Zhang et al. 2012). Currently, resistance management tactics use large refuges and pyramiding approaches to maintain low inherent resistance of cotton bollworm to $\mathrm{Bt}$ toxins. Bt cotton production is also integrated with other pest management tactics. These are promising approaches and useful techniques for managing bollworm resistance in $B t$ cotton. Some refuge crops such as corn, soybean, and peanut have been screened and assessed (Carriere et al. 2016; Jin et al. 2015; Lu et al. 2013; Wu et al. 2002). The experimental model used in this study of planting $B t$ cotton in large areas with non- $B t$ crops present (e.g., watermelon, peanut, corn, pepper, and sorghum) has been extensively used in North China (Fig. 1a to e) for the past eight years.

However, investigations on variations in field resistance to bollworms in different $B t$ cotton production varieties over an extended period are limited. The area under $B t$ cotton production in the three provinces has decreased in favor of other major crops in the last 8 years (Additional file 1: Table S3, Additional file 2: Figure S1). Changes in Bt insecticidal protein concentration of the $B t$ cotton varieties planted during this time have been monitored using enzyme-linked immunosorbent assays (ELISA). The effects on cotton bollworms of Bt insecticidal protein samples collected from 197 Bt cotton varieties were determined using bioassays.

The major aims of this study were to investigate variations in the field resistance to cotton bollworms of 197 Bt cotton varieties (Additional file 1: Table S1-1) in three major cultivation provinces (Hebei, Shandong, and Henan; Additional file 1: Table S2) for an extended period (8 years) and to evaluate the efficiency of different $B t$ cotton varieties in controlling cotton bollworm in North China.

\section{Methods \\ Experimental Bt cotton varieties, locations, and planting patterns}

A total of 197 transgenic $B t$ cotton varieties were monitored for Bt-induced mortality of cotton bollworm and the ability of $B t$ cotton to control cotton bollworm in the field from 2008 to 2015 (Additional file 1: Table S1-1). These $B t$ cotton varieties included 113 unique varieties in different locations and years (Additional file 1: Table S1-2). These experimental Bt cotton varieties were supplied by the county and planted 42 locations (Additional file 1: Table S2) in Henan, Hebei, and Shandong provinces in North China.
The same Bt cotton varieties were planted at the East experimental farm $\left(36^{\circ} 5^{\prime} 34.8^{\prime \prime} \mathrm{N}, 114^{\circ} 31^{\prime} 47.19^{\prime \prime} \mathrm{E}\right)$ of the Institute of Cotton Research of Chinese Academy of Agricultural Sciences every year, and the buds, leaves, and bolls of these varieties were collected and used in the bioassays and Bt protein analyses from 2008 to 2015.

The area planted with $B t$ cotton is continually decreasing (Additional file 1: Table S3, Additional file 2: Figure S1). The experimental planting patterns consisted of $B t$ cotton situated adjacent to corn, watermelon, pepper, sorghum, and peanut (Fig. 1a to e).

\section{Field investigations}

Three field investigations to determine the number of $B t$-induced live cotton bollworm larvae were conducted in the period June, July and August each year from 2008 to 2015. A total of four generations of cotton bollworm emerged during May and August each year in North China, generally in a cycle of one generation per month. The first generation of cotton bollworm fed on wheat during May 10 to June 10. Upon maturity and harvest of wheat, cotton bollworms transferred to the cotton field to lay eggs after June 10, which was named as the second generation of cotton bollworms. Regarding the life history of cotton bollworm, we conducted field investigations during the peak period of cotton bollworm larvae proliferation, from the second to fourth generation larval stage of cotton bollworm during the third 10-day period every month.

We investigated three sites forming a triangle for each $B t$ cotton variety. And twenty plants were selected per site. We recorded the number of cotton bollworm larvae, damaged tip-stems, buds, and bolls, and healthy buds and bolls.

\section{Bioassay of cotton bollworms}

Newly-hatched cotton bollworm larvae of the first generation were used in the bioassays. The populations of larvae were all $B t$-susceptible and were maintained separately at $(25 \pm 1){ }^{\circ} \mathrm{C}$ and $60-70 \%$ relative humidity $(\mathrm{RH})$, with a photoperiod of $16 \mathrm{~h}: 8 \mathrm{~h}(\mathrm{~L}: \mathrm{D})$.

The leaf-feeding bioassay method was performed based on the national standard (Ministry of Agriculture of China, 2013b). Briefly, five cotton bollworms of the first generation were fed with cotton leaves, with 20 leaves per variety with three replicates. The newly-hatched first-generation larvae were used in the bioassays that were conducted from the mid-June to August each year. We selected 20 healthy cotton leaves from each variety, which were placed in a plastic bioassay box (4-cm diameter $\times 4$-cm high), onto which five newly-hatched larvae were gently placed. After that, bioassay boxes were placed in a culture room $\left(26-28{ }^{\circ} \mathrm{C}, \mathrm{RH}\right.$ $=60 \%$ ). The CK (CCRI 49) variety was used as the non-Bt 
a

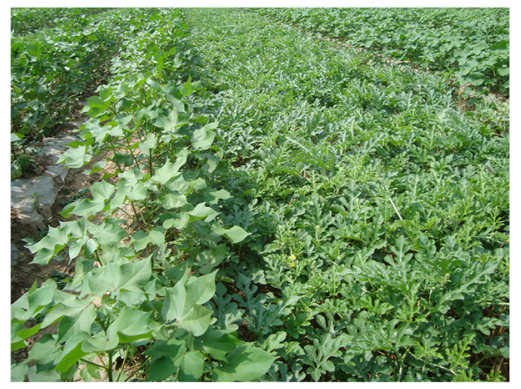

C

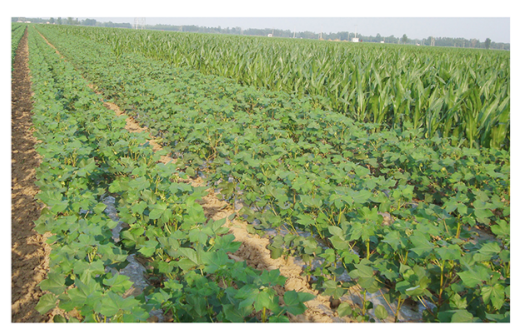

b

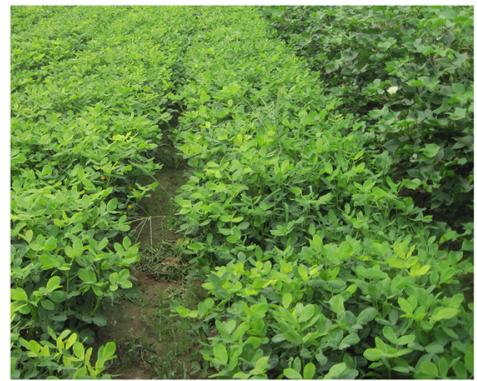

d

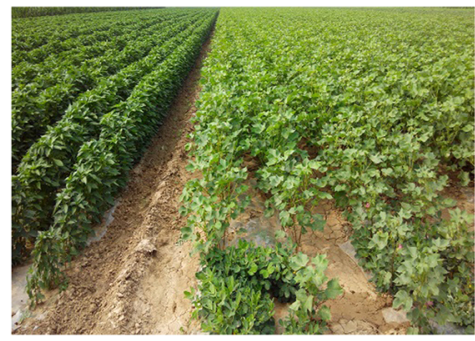

e

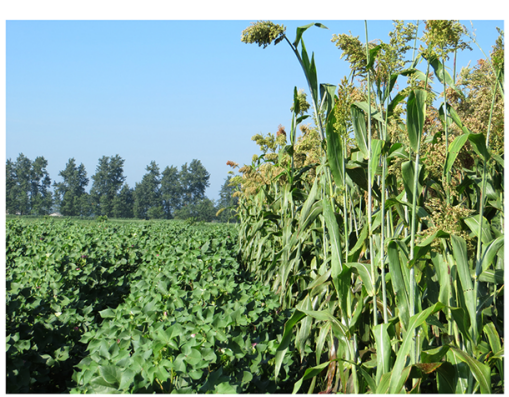

Fig. 1 The planting pattern of $B t$ cotton with other crops in the different locations (a to e). a The intercropping of $B t$ cotton and watermelon. $\mathbf{b} B t$ cotton adjacent peanuts. $\mathbf{c} B t$ cotton adjacent corn. $\mathbf{d} B t$ cotton adjacent peppers. e Bt cotton adjacent sorghum

cotton control. After five days, the number of dead larvae was recorded.

\section{Bt protein content analysis using ELISA}

Each of the $B t$ cotton varieties was planted in three experimental plots as three replicates. Bt protein concentrations in all of $B t$ cotton varieties planted on the East experimental farm of the Institute of Cotton Research of CAAS were determined by ELISA according to standardized methods (Ministry of Agriculture of China, 2013a) using QualiPlate ${ }^{\mathrm{Tw}}$ Kit for Cry1Ab/Cry1Ac (Envirologix Inc., 500 Riverside Industrial Parkway, Portland, Maine, United States) each year. Twenty leaves from all experimental $B t$ cotton varieties were collected, and then rapidly immersed in liquid nitrogen. All samples were transported back to the laboratory. The 20 fresh cotton leaves of each variety were ground, and then $0.4 \mathrm{~g}$ of each powdered sample was used to extract Bt protein, following the instructions provided in the QualiPlate ${ }^{\mathrm{mm}}$ kit for Cry1Ab/Cry1Ac.

\section{Data analysis}

The data were analyzed using Microsoft Excel 2007 and DPS 7.0. Standard errors of data were calculated using the STDEV and SQRT functions. The following equations were used in the calculations (Püntener, 1981):

$$
\begin{aligned}
& \text { Ratio of damaged tip-stem }(\%) \\
& =\frac{\text { Number of damaged tip-stem }}{\text { Number of survey plants }} \times 100 ;
\end{aligned}
$$

Ratio of damaged buds and bolls (\%)

$$
\begin{aligned}
= & \frac{\text { Number of damaged buds and bolls }}{\text { Number of damaged buds and bolls }} \times 100 ; \\
& + \text { Number of healthy buds and bolls }
\end{aligned}
$$

$$
\text { Ratio of mortality }(\%)=\frac{\text { Number of dead insects }}{\text { Total number of cotton bollworms }}
$$


Corrected mortality $(\%)=$ Mortality $\%$ in the treated plot-

$$
\frac{\text { Mortality\% in the control plot }}{100-\text { Mortality\% in the control plot }} \times 100 \text {. }
$$

\section{Results}

Monitoring of cotton bollworms in the field

Cotton bollworm larvae on $\mathrm{Bt}$ cotton varieties were investigated from 2008 to 2015 . The results showed that the number of cotton bollworm larvae peaked in 2011, the only year in which the average number of cotton bollworm larvae per 100 plants exceeded the action threshold of 10 larvae at the second cotton bollworm generation stage. In the other years, the average number of cotton bollworm larvae of all varieties per 100 plants remained below the action threshold (Fig. 2a) for all stages. The average number of cotton bollworms remained below the action threshold at the third and fourth cotton bollworm generation stages in seven of the 8 study years (Fig. 2b and c). Standard deviations were calculated for the samples of cotton bollworm larvae collected from all investigated cotton varieties (Fig. 2 a to $\mathrm{c}$ ).

The study results also revealed the ratio and the number of varieties exceeding the action threshold as well as the bollworm mortality induced by Bt protein in each cotton bollworm generation from 2008 to 2015 (Table 1). Our results indicated that, in 2011, 9 of the 22 varieties exceeded the action threshold at the second cotton bollworm generation stage. Similarly, in 2009, 5 of 29 varieties exceeded the action threshold at the second and third cotton bollworm generation stages. Whereas during other years, the number of the varieties reached the action threshold was less than
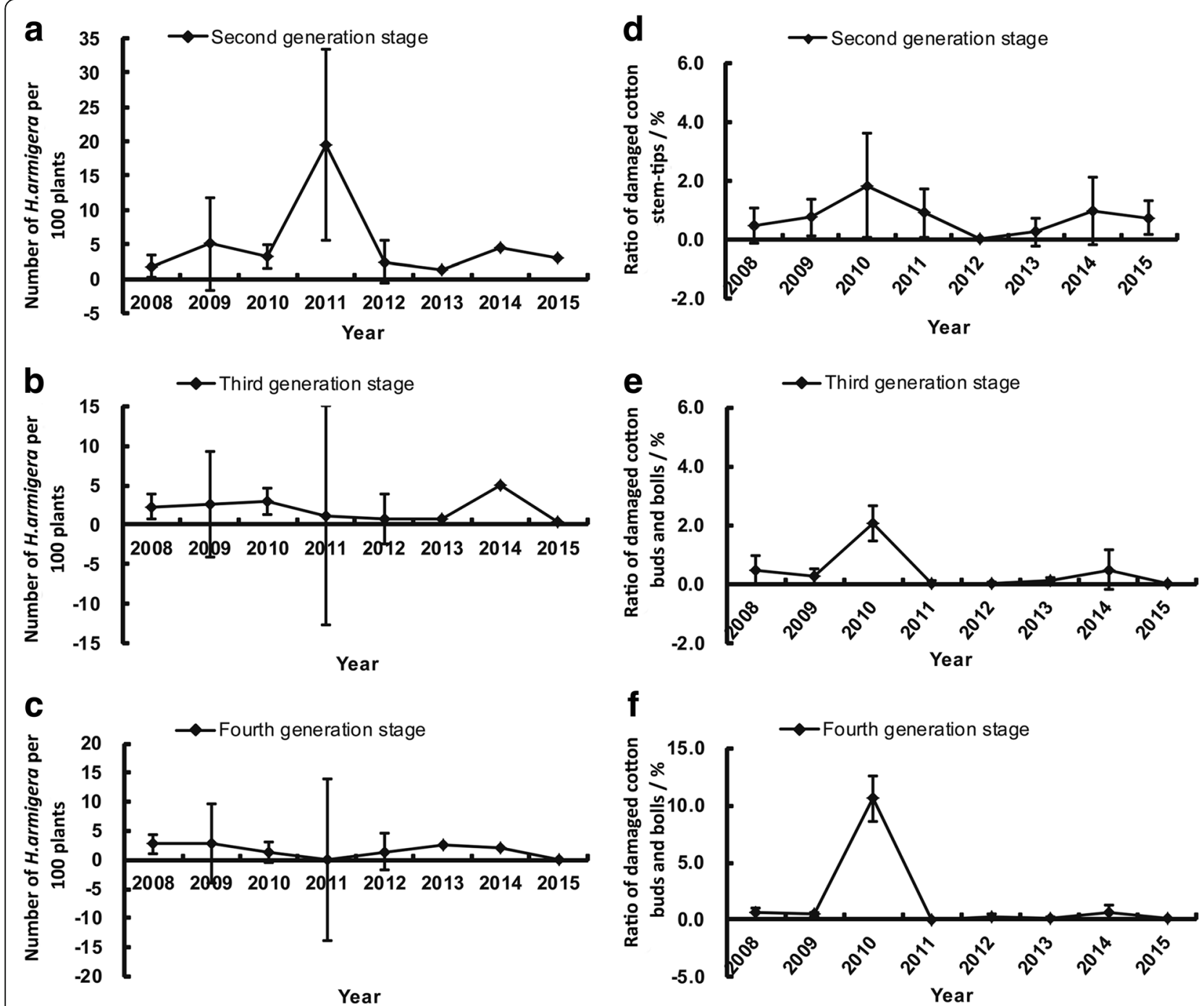

Fig. 2 The changes in the number of cotton bollworms and the ratios of damaged cotton stem-tips, buds, and bolls. a to c Changes in the number of cotton bollworms found at the second, third and fourth cotton bollworm generation stages from 2008 to 2015 ; $\mathbf{d}$ to $\mathbf{f}$ The ratios of damaged cotton stem-tips, buds, and bolls from 2008 to 2015. The error bars are SEs 
Table 1 The percentages and number exceeding the action threshold for each cotton bollworm generation from 2008 to 2015

\begin{tabular}{|c|c|c|c|c|c|c|c|}
\hline \multirow[t]{2}{*}{ Year } & \multirow{2}{*}{$\begin{array}{l}\text { Number } \\
\text { of } \\
\text { varieties }\end{array}$} & \multirow{2}{*}{ 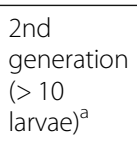 } & \multirow{2}{*}{ 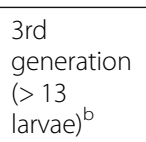 } & \multirow{2}{*}{ 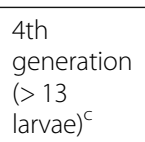 } & \multicolumn{3}{|c|}{ Ratios $^{\mathrm{d}}$ per generation/\% } \\
\hline & & & & & 2nd & $3 r d$ & 4th \\
\hline 2008 & 35 & 0 & 1 & 2 & 0.0 & 2.9 & 5.7 \\
\hline 2009 & 29 & 5 & 3 & 2 & 17.2 & 10.3 & 6.9 \\
\hline 2010 & 22 & 0 & 1 & 0 & 0.0 & 4.5 & 0.0 \\
\hline 2011 & 22 & 9 & 0 & 0 & 40.9 & 0.0 & 0.0 \\
\hline 2012 & 21 & 1 & 0 & 0 & 4.8 & 0.0 & 0.0 \\
\hline 2013 & 21 & 1 & 0 & 0 & 4.8 & 0.0 & 0.0 \\
\hline 2014 & 23 & 2 & 3 & 1 & 8.7 & 13.0 & 4.3 \\
\hline 2015 & 24 & 2 & 0 & 0 & 8.3 & 0.0 & 0.0 \\
\hline
\end{tabular}

${ }^{\mathrm{a}} 2 \mathrm{nd}$ ( $>10$ larvae), the number of varieties that exceeded the 10-larvae per 100 cotton plants action threshold at the second generation of cotton bollworms

${ }^{b} 3$ rd (>13 larvae), the number of varieties that exceeded the 13-larvae per 100 cotton plants action threshold at the third generation of cotton bollworms

${ }^{c} 4$ th (> 13 larvae), the number of varieties that exceeded the 13-larvae per 100 cotton plants action threshold at the fourth generation of cotton bollworms

${ }^{\mathrm{d}}$ Ratio $(\%)=\frac{\text { 2nd }(>10 \text { larvae }) \text {,3rd }(>13 \text { larvae }) \text {, or 4th }(>13 \text { larvae }) \text { generation }}{\text { Number of varieties }} \times 100$

2011 and 2009 at the second and third generations. The results showed there were differences in the cotton bollworm resistance ability among different $\mathrm{Bt}$ cotton varieties.

\section{Ratio of damaged stem-tips, buds, and bolls}

The ratio of damaged tip-stems is an essential evaluation index of Bt cotton resistance to cotton bollworms at the second cotton bollworm generation. The highest ratio of damaged tip-stems was $1.82 \%$, whereas the average ratio ranged from 0.00 to $0.95 \%$ (Fig. 2d). The ratio of damaged buds and bolls is an essential evaluation index for $B t$ cotton resistance at the third and fourth cotton bollworm generation (Fig. 2e and f). The results indicate that the highest ratios of damaged buds and bolls were $2.09 \%$ and $10.63 \%$ respectively, at the third and fourth cotton bollworm generation in 2010.

\section{Bioassay analysis}

The corrected bollworm mortalities of the tested Bt cotton varieties were recorded for each cotton bollworm generation. The corrected Bt-induced mortality at the second cotton bollworm generation stage was higher than at the third and fourth cotton bollworm generations in most years from 2008 to 2015 . The corrected mortality at the second cotton bollworm generation stage initially increased, then subsequently decreased. Moreover, the average corrected mortality of all varieties exceeded $90 \%$ in 2010 and 2011, which was the highest resistance level (Fig. 3a). However, the resistance level has declined in the past few years.

The overall resistance level decreased at the third and fourth cotton bollworm generations from 2008 to 2015 (Fig. $3 \mathrm{~b}$ and c). Bt-induced mortality ranged from $19.13 \%$ to $48.35 \%$ in the third cotton bollworm generation from 2008 to 2015 and from $11.86 \%$ to $84.46 \%$ in the fourth cotton bollworm generation (Fig. 3c).

\section{Changes in Bt protein content}

Bt protein content at the seedling, bud and boll stages from 2008 to 2015 was assessed using ELISA. Bt protein content significantly differed at various developmental stages. At the seedling stage, the Bt protein content decreased from 2008

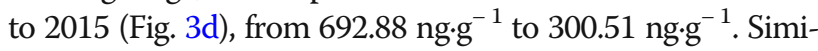
larly, Bt protein content in the bud-stage leaves decreased from $371.24 \mathrm{ng} \cdot \mathrm{g}^{-1}$ to $158.89 \mathrm{ng} \cdot \mathrm{g}^{-1}$ from 2008 to 2015 , and that of boll-stage leaves decreased from $435.56 \mathrm{ng} \cdot \mathrm{g}^{-1}$ to $100.51 \mathrm{ng} \cdot \mathrm{g}^{-1}$ (Fig. 3e and f).

\section{Discussion}

The results of this study indicate that $B t$ cotton varieties currently under production are capable of controlling cotton bollworms, although the field results showed that different varieties have varying levels of bollworm resistance. Field monitoring shows that most of the main cotton varieties are effective in controlling the cotton bollworm population. The average number of cotton bollworms exceeded the action threshold in only 1 year during the 8-year study period and generally remained below the action threshold in most of the $B t$ cotton varieties (Table 1, Fig. 2a).

In 2011, we investigated infestation of cotton bollworms during the second-generation stage at Nanpi County in Hebei. At this location, there was a variety of weeds growing around the cotton field. These weeds provided abundant hosts for the bollworm population (Rajapakse and Walter, 2007). It was speculated that this might be one reason for more cotton bollworms at Nanpi in this year. In 2010, there was a high ratio of damaged cotton buds and bolls at the fourth generation stage. The main reason was cotton boll rot, caused by above-average rainfall in July and August of this year.

The bioassay results of this study demonstrated that $B t$-induced bollworm mortality decreased in the second cotton bollworm generation, which is one of the most 


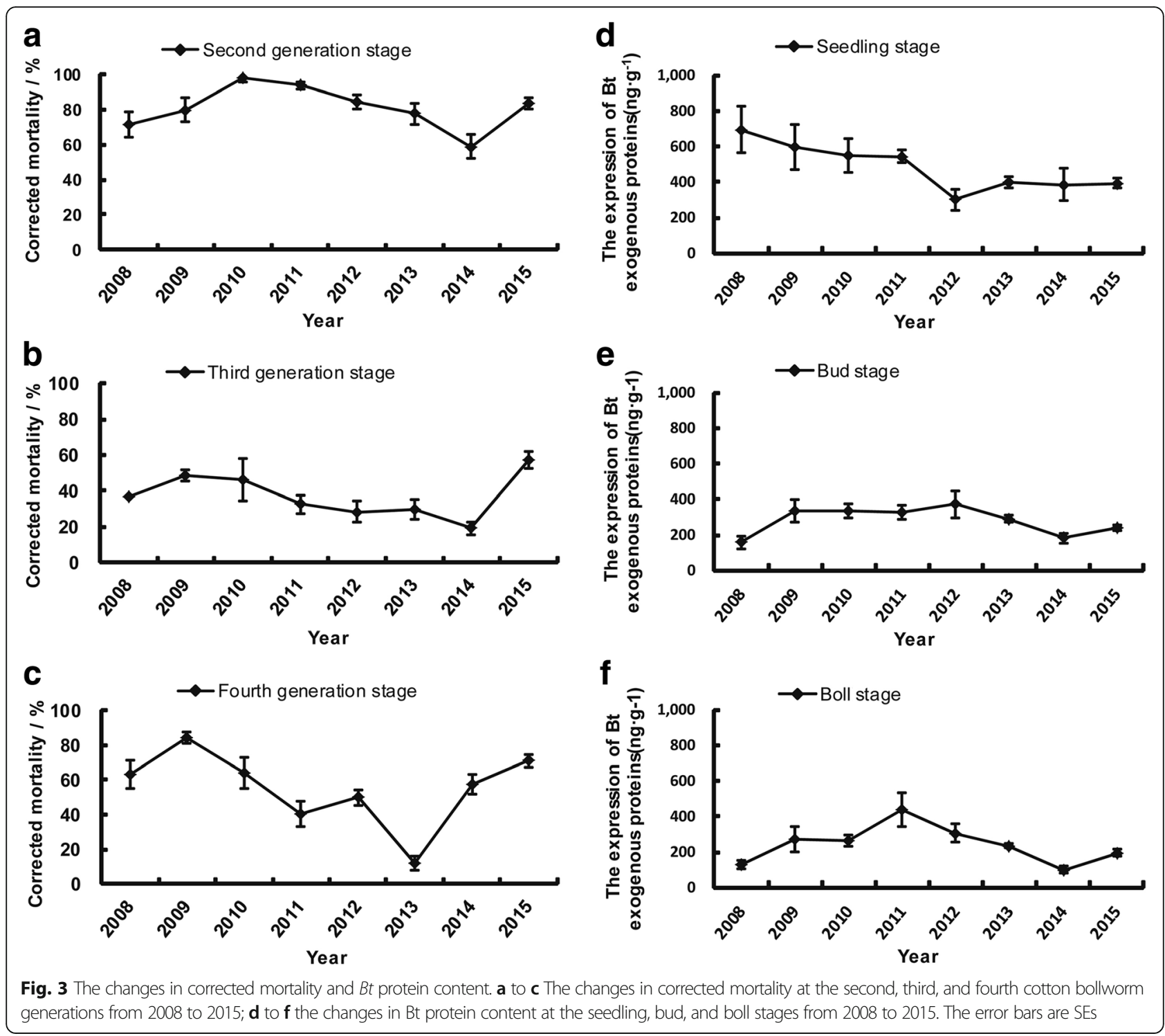

destructive generations for cotton. This implies that the cotton bollworms can evolve resistance to $B t$ cotton; resistant insects have been produced on $B t$ cotton both in the field and in the laboratory (Liang et al. 2008; Tabashnik et al. 2003; Zhang et al. 2011). In addition, in field-selected populations, most resistance alleles occur as heterozygotes, and 59-94\% of resistant individuals carried at least one recessive resistance allele, even though the resistance level to $B t$ cotton was low (Zhang et al. 2012).

These reports show that the mechanism of resistance to cotton bollworm is complex. However, the change in mortality ratio or resistance may be the result of reduced Bt insecticidal protein concentration in $B t$ cotton. The ELISA results showed that the $B t$ cotton Cry1Ac contents in seedlings significantly decreased from 2008 to 2015. The reduced Cry1Ac contents in $B t$ cotton were correlated with changes in bollworm mortality in the field. This result shows that the bollworms develop resistance to current cotton varieties; therefore, new cotton varieties with multi-resistance to bollworm should be developed to delay the evolution of bollworm resistance to $B t$ cotton in the field (Baker and Tann, 2014; Ye et al. 2015). Consequently, the pyramid strategy for delaying the evolution of pest resistance to $B t$ crops is apparently risky (Brevault et al. 2013; Carriere et al. 2015). The use of natural refuge crops is a good strategy to delay cotton bollworm resistance (Baker and Tann 2014; Ye et al. 2015).

The results of our bioassay and ELISA showed some years were unusual in terms of corrected mortality and Bt protein. This might be due to significant differences in temperature and rainfall in 2009 and 2014. Results of previous studies have shown that the efficacy of $B t$ cotton plants is affected by environmental factors such as changes in light intensity, water and nitrogen availability 
or insect and wind damage. Differing environmental conditions can regulate the transcript levels of $c r y 1 A c$, and specifically modulate $B t$ gene expression (Trtikova et al. 2015; Wan et al. 2005).

The results of the present study reveal that the most practical strategy to control the bollworm population is to plant different $B t$ cotton varieties. $B t$ cotton varieties from different breeding units play an important role in restraining cotton bollworm damage. Employing refuge crops that are designed to increase the dominance or magnitude of fitness is particularly useful in delaying pest resistance (Gassmann et al. 2009). Adjacent non-Bt crops that function as bollworm host plants may provide sufficient natural refuges to delay the evolution of bollworm resistance to $B t$ cotton (Carriere et al. 2016; Jin et al. 2015). The results of this 8-year study show that planting $B t$ cotton with any other non- $B t$ crops is a strategy that may have contributed to the control of the bollworm population.

\section{Conclusions}

This study evaluated 197 Bt cotton varieties (113 unique varieties) planted in 42 counties/locations of three provinces in northern China. Field investigations, bioassays, and ELISA indicated that different $B t$ cotton varieties were inherently equipped to control the damage incurred by cotton bollworms, and almost all $B t$ cotton varieties effectively controlled the populations of cotton bollworm during the years investigated.

\section{Additional files}

Additional file 1: Table S1-1. Bt cotton varieties monitored from 2008 to 2015. Table S1-2. Single Bt cotton varieties after repeat planted varieties were deleted from 2008 to 2015. Table S2. The study sites that were investigated from 2008 to 2015. Table S3. Plantation area for cotton and other crops that were assessed from 2008 to 2015. (XLSX $31 \mathrm{~kb}$ )

Additional file 2: Figure S1. The percentage of planted Bt cotton area monitored from 2008 to 2015. (TIF $149 \mathrm{~kb}$ )

\section{Acknowledgments}

We thank Cotton Technological Guidance Station of Shandong Province, Cash Crops Technological Guidance Station of Hebei Province and Cash Crops Extension Station of Henan Province in China.

\section{Funding}

This research was supported by the project of China Agriculture Research System (CARS-15-20)

\section{Availability of data and materials}

Data sharing not applicable to this article as no datasets were generated or analyzed during the current study.

\section{Authors' contributions}

Cui JJ and Ma Y conceived and designed the experiments. Lü LM and LuO JY contributed equally to this work. Lü LM, Luo JY, Zhang S, Yu QL, Ma LG, Liu XF, Wang CY and Ma XY analysed the data and prepared the figures and tables. Lü LM wrote the manuscript. All of the authors reviewed the manuscript. All authors read and approved the final manuscript.
Ethics approval and consent to participate

Not applicable.

\section{Consent for publication}

Not applicable.

\section{Competing interests}

The authors declare that they have no competing interests.

\section{Publisher's Note}

Springer Nature remains neutral with regard to jurisdictional claims in published maps and institutional affiliations.

\section{Author details}

${ }^{1}$ Institute of Cotton Research, Chinese Academy of Agricultural Sciences (CAAS), State Key Laboratory of Cotton Biology, Anyang 455000, Henan, China. ${ }^{2}$ Cotton Technological Guidance Station of Shandong Province, Jinan 250000, China. ${ }^{3}$ Cash Crops Technological Guidance Station of Hebei Province, Shijiazhuang 050000, China. ${ }^{4}$ Cash Crops Extension Station of Henan Province, Zhengzhou 450000, China.

Received: 30 March 2018 Accepted: 28 May 2018

Published online: 29 June 2018

\section{References}

Baker GH, Tann CR. Refuge crop performance as part of the Bt resistance management strategy for Helicoverpa spp. (Lepidoptera: Noctuidae) in Australian cotton production systems. Aust J Entomol. 2014;53(2):240-7. https://doi.org/10.1111/aen.12072

Brevault T, Heuberger S, Zhang M, Ellers-Kirk C, Ni XZ, Masson L, et al. Potential shortfall of pyramided transgenic cotton for insect resistance management. Proc Natl Acad Sci U S A. 2013;110(15):5806-11. https://doi.org/10.1073/pnas.1216719110.

Carriere Y, Crickmore N, Tabashnik BE. Optimizing pyramided transgenic Bt crops for sustainable pest management. Nat Biotechnol. 2015;33(2):161-8. https://doi.org/10.1038/nbt.3099.

Carriere Y, Fabrick JA, Tabashnik BE. Can pyramids and seed mixtures delay resistance to Bt crops? Trends Biotechnol. 2016;34(4):291-302. https://doi.org/10.1016/j.tibtech.2015.12.011.

Dhurua S, Gujar GT. Field-evolved resistance to Bt toxin Cry1Ac in the pink bollworm, Pectinophora gossypiella (Saunders) (Lepidoptera: Gelechiidae), from India. Pest Manag Sci. 2011;67(8):898-903. https://doi.org/10.1002/ps.2127.

Gassmann AJ, Carriere Y, Tabashnik BE. Fitness costs of insect resistance to Bacillus thuringiensis. Annu Rev Entomol. 2009;54:147-63. https:// doi.org/10.1146/annurev.ento.54.110807.090518.

Gunning RV, Dang HT, Kemp FC, Nicholson IC, Moores GD. New resistance mechanism in Helicoverpa armigera threatens transgenic crops expressing Bacillus thuringiensis Cry1Ac toxin. Appl Environ Microbiol. 2005;71(5):255863. https://doi.org/10.1128/AEM.71.5.2558-2563.2005.

Jin L, Zhang HN, Lu YH, Yang YH, Wu KM, Tabashnik BE, et al. Large-scale test of the natural refuge strategy for delaying insect resistance to transgenic Bt crops. Nat Biotechnol. 2015;33(2):169-74. https://doi.org/10.1038/nbt.3100.

Liang GM, Wu KM, Yu HK, Li KK, Feng X, Guo YY. Changes of inheritance mode and fitness in Helicoverpa armigera (Hubner) (Lepidoptera: Noctuidae) along with its resistance evolution to Cry1Ac toxin. J Invertebr Pathol. 2008;97(2): 142-9. https://doi.org/10.1016/j.jip.2007.09.007.

Liu FY, Xu ZP, Zhu YC, Huang FN, Wang YH, Li HL, et al. Evidence of field-evolved resistance to Cry1Ac-expressing Bt cotton in Helicoverpa armigera (Lepidoptera: Noctuidae) in northern China. Pest Manag Sci. 2010;66(2):15561. https://doi.org/10.1002/ps.1849.

Lu ZZ, Zalucki MP, Perkins LE, Wang DY, Wu LL. Towards a resistance management strategy for Helicoverpa armigera in Bt-cotton in northwestern China: an assessment of potential refuge crops. J Pest Sci. 2013;86(4):695703. https://doi.org/10.1007/s10340-013-0517-7.

Ministry of Agriculture of China. Detection of genetically modified plants and derived products-technical specification for quantitative detection of exogenous proteins in Bt transgenic cotton: No. of 1485 announcement of Ministry of Agriculture, 14-2010. Beijing: Ministry of Agriculture, China; 2013a.

Ministry of Agriculture of China. Evaluation of environmental impact of genetically modified plants and it's derived products - insect-resistant cotton part 1: evaluation of insect pest resistance: No. of 1943 announcement of Ministry of Agriculture-3-2013. Beijing: Ministry of Agriculture, China; 2013b. 
Püntener W. Manual for field trials in plant protection. 2nd ed. Basle: CibaGeiji Limited; 1981.

Rajapakse CNK, Walter GH. Polyphagy and primary host plants: oviposition preference versus larval performance in the lepidopteran pest Helicoverpa armigera. Arthropod Plant Interact. 2007;1 (1):17-26. https://doi.org/10.1007/s1 1829-007-9003-6.

Tabashnik BE, Carriere Y, Dennehy TJ, Morin S, Sisterson MS, Roush RT, et al. Insect resistance to transgenic Bt crops: lessons from the laboratory and field. J Econ Entomol. 2003;96(4):1031-8. https://doi.org/10.1093/jee/96.4.1031.

Trtikova M, Wikmark OG, Zemp N, Widmer A, Hilbeck A. Transgene expression and Bt protein content in transgenic Bt maize (MON810) under optimal and stressful environmental conditions. PLoS One. 2015; 10(4):e0123011. https://doi.org/10.1371/journal.pone.0123011.

Van Rensburg JBJ. First report of field resistance by the stem borer, Busseola fusca (fuller) to Bt-transgenic maize. S Afr J Plant Soil. 2007;24(3):147-51. https://doi.org/10.1080/02571862.2007.10634798.

Wan P, Zhang Y, Wu K, Huang M. Seasonal expression profiles of insecticidal protein and control efficacy against Helicoverpa armigera for Bt cotton in the Yangtze River valley of China. J Econ Entomol. 2005;98(1):195-201.

Wu KM, Guo YY. The evolution of cotton pest management practices in China. Annu Rev Entomol. 2005;50:31-52. https://doi.org/10.1146/annurev.ento.50. 071803.130349.

Wu KM, Guo YY, Gao SS. Evaluation of the natural refuge function for Helicoverpa armigera (Lepidoptera : Noctuidae) within Bacillus thuringiensis transgenic cotton growing areas in North China. J Econ Entomol. 2002;95(4):832-7. https://doi.org/10.1603/0022-0493-95.4.832.

Wu KM, Lu YH, Feng HQ, Jiang YY, Zhao JZ. Suppression of cotton bollworm in multiple crops in China in areas with Bt toxin-containing cotton. Sci. 2008; 321(5896):1676-8. https://doi.org/10.1126/science.1160550.

Ye LF, Fu X, Ouyang F, Xie BY, Ge F. Determining the major Bt refuge crops for cotton bollworm in North China. Insect Sci. 2015;22(6):829-39. https://doi.org/10.1111/1744-7917.12171.

Zhang HN, Tian W, Zhao J, Jin L, Yang J, Liu CH, et al. Diverse genetic basis of fieldevolved resistance to Bt cotton in cotton bollworm from China. Proc Natl Acad Sci U S A. 2012;109(26):10275-80. https://doi.org/10.1073/pnas.1200156109.

Zhang HN, Yin W, Zhao J, Jin L, Yang YH, Wu SW, et al. Early warning of cotton bollworm resistance associated with intensive planting of Bt cotton in China. PLoS One. 2011;6(8) https://doi.org/10.1371/journal.pone.0022874.

Zhang SP, Cheng HM, Gao YL, Wang GR, Liang GM, Wu KM. Mutation of an aminopeptidase $\mathrm{N}$ gene is associated with Helicoverpa armigera resistance to bacillus thuringiensis Cry1Ac toxin. Insect Biochem Mol Biol. 2009;39(7): 421-9. https://doi.org/10.1016/j.ibmb.2009.04.003.

\section{Ready to submit your research? Choose BMC and benefit from:}

- fast, convenient online submission

- thorough peer review by experienced researchers in your field

- rapid publication on acceptance

- support for research data, including large and complex data types

- gold Open Access which fosters wider collaboration and increased citations - maximum visibility for your research: over $100 \mathrm{M}$ website views per year

At BMC, research is always in progress.

Learn more biomedcentral.com/submissions 